\title{
Learning Innovative Methodologies to Foster Personal, Organizational and Community Empowerment through Online and Face- to-Face Community Psychology Courses*
}

\author{
Aprendiendo metodologías innovadoras para fomentar el \\ empoderamiento personal, organizacional y comunitario a través \\ de cursos de psicología comunitaria en línea y cara a cara
}

Enviado: 1º de marzo de 2015 | Revisado: 1o de junio de 2015 | Aceptado: 1o de agosto de 2015

\author{
DONATA Francescato** \\ University of Rome, La Sapienza, Italia \\ MinOU MeBAnE *** \\ University of Rome, Unitelma Sapienza, Italia
}

doi:10.1114/Javeriana.upsy14-4.limf

Para citar este artículo: Francescato, D., \& Mebane, M. (2015) Learning Innovative Methodologies to Foster Personal, Organizational and Community Empowerment through Online and Face-to-Face Community Psychology Courses. Universitas Psychologica, 14(4), 1209-1220. http:// dx.doi.org/10.1114/Javeriana.upsy14-4.limf

* Artículo de investigación

***20938@mclink.it

\section{A B S T R A C T}

This paper aims to illustrate the contextual factors that inspired some Italian community psychologists to develop three innovative intervention methodologies to foster personal, organizational and community empowerment. We also summarize several studies we conducted to explore the comparative efficacy of traditional and more innovative online teaching, in helping community psychology students master the competencies needed to carry out these three different intervention modalities. These studies showed that both face-to-face and online collaborative learning settings were effective not only in promoting students' professional competencies, but also in enhancing their social capital and sociopolitical empowerment. Implications for a wider use of online settings to share community psychology values, principles and practices elaborated in different parts of the world are discussed.

Keywords

community psychology methodologies; CSCL (Computer Supported Collaborative

Learning); socio-political empowerment; community profiling; participatory

multidimensional organizational analysis

\section{RESUMEN}

El objetivo de este trabajo es ilustrar los factores contextuales que inspiraron a algunos psicólogos comunitarios italianos a desarrollar tres metodologías de intervención innovadoras que fomentan el empoderamiento personal, organizacional y comunitario. También se resumen varios estudios que llevamos a cabo para explorar la eficacia comparativa entre la enseñanza tradicional y una línea online más innovadora, ayudando de esta manera a estudiantes de psicología comunitaria en el dominio de las competencias requeridas para desarrollar estas tres modalidades diferentes de intervención. Estos estudios demostraron que tanto el aprendizaje cara a cara como el colaborativo online fueron eficaces no solo en la promoción de las competencias profesionales de los estudiantes, sino también en el aumento de su capital social y empoderamiento sociopolítico. Se discute la aplicación más amplia de configuraciones online para compartir los valores, principios y prácticas de la psicología comunitaria elaboradas en diferentes partes del mundo.

Palabras clave

metodologías de psicología comunitaria; CSCL; empoderamiento sociopolítico; perfiles comunitarios; análisis participativo multidimensional de las organizaciones 
This paper has two main aims. First to illustrate the contextual factors and the theoretical principles that inspired some Italian community psychologists to develop three innovative intervention methodologies: a) community profiling to foster community empowerment; $b$ ) participatory multidimensional organizational analysis to promote organizational empowerment and c) sociopolitical empowerment training to promote individual personal and sociopolitical empowerment. In the first part of this paper we briefly discuss how European and in particular Italian community psychologists felt the need to distinguish themselves from USA based community psychology and to develop a more European approach to community psychology. We present the main characteristics of each of three methodologies developed primarily by Italian community psychologists in the eighties, which in the last two decades, have been enriched by contributions from other European colleagues after the creation of the European Networks of Community Psychologists (ENCP) in 1995 and the formation of European Community Psychological Association (ECPA) in 2005.

The second aim is to contribute to the ongoing debate on how online platform can help disseminate community psychologies theories and intervention methodologies developed in various areas of the world documenting how collaborative learning online settings can be used to teach community psychology to students who cannot attend regular face-to-face courses. Therefore in the second part of this paper we summarize several studies conducted in the last fourteen years to explore the comparative efficacy of traditional and more innovative online teaching, and in helping community psychology students master the competencies needed to carry out these three different intervention modalities. Moreover, we discuss implications for a wider use of online settings to share community psychology values, principles and practices elaborated in different parts of the world.

\section{Contextual factors and theoretical principles, which inspired the development of innovative methodologies to foster multilevel empowerment}

In the seventies European community psychologists began to differentiate partially from their USA colleagues on how to conduct interdisciplinary action research. They hypothesized that to promote change it was not necessary to form teams of experts from different fields, but to utilize the knowledge and methodologies produced in various disciplines. Another common criticism of the dominant USA model was the paucity of publications of interventions aimed at organizational issues. In the eighties Italian community psychology practitioners and academics worked together to develop two interdisciplinary intervention methodologies: Community profiling to promote community empowerment (Martini \& Sequi, 1988) and Participatory Multidimensional Organizational Analysis (PMOA) to enhance organizational empowerment (Francescato \& Ghirelli, 1988). These two methodologies were first presented internationally in 1992 in a community psychology conference in Lisbon and attracted much interest. In 1995 the creation of the European Network of Community Psychologists (ENCP) and the promotion of annual international meetings Munich (1996), Vienna (1997) Stirling (1999) Lecce (2001), Leuven (2003) and Naples (2005), and biennial ENCP congresses (Lisbon (1998), Bergen (2000), Barcelona (2002), Berlin (2004)) favored the discussion among European community psychologists on values, theoretical guiding principles and modes of intervention. Donata Francescato as coordinator of ENCP was invited to teach Community profiling and Participatory Multidimensional Organizational Analysis in Germany, Austria, Scotland, England and Portugal where Jose Ornelas organized the first Master in Community Psychology with international faculty members. Both intervention strategies were therefore improved by the contributions made by several European community psychologists, especially after the creation of the European Community Psychology Association (ECPA) in Naples 
in 2005 (Arcidiacono, 2013; Ehmayer, Reinfeldt \& Gtotter, 2000; Francescato \& Zani, 2010; Ornelas, 2008). This exchange among community psychologists coming from different countries favored the integrations of theoretical principles and interventions strategies into what was named 'An European approach' to community psychology. The main chacteristics of an European approach can be synthetized as a) stressing the historical link between the process of giving value to individual freedom and collective struggles; b) developing new theoretical frameworks integrating constructivist and neo-positivist perspectives, and critical and liberation perspectives; c) promoting more sociopolitical empowerment and bridging social capital; d) reexamining various historical meanings of community and examining the negative aspects of sense of community; and e) underlining the necessity to develop theory driven intervention strategies beyond the individual and small group level (Amerio, 2000; Arcidiacono, 2013; Francescato \& Tomai, 2001; Orford, 2008). A lively debate is still going on in Europe. Some European community psychologists feel a need to develop more multilevel empowerment tools, and take an active part in the international debate on community psychology competences, while others are more interested in integrating the political insights of critical and liberation psychologies. Berghold and Seckinger (2007) maintain that while community psychologists in Germany appreciate a critical psychology perspective many practitioners feel that a reflective attitude is not enough in a situation in which financial and personal resources are reduced and efficiency is demanded, and underline the need to develop clearly defined professional tools. Also two Spanish community psychologists (Martin \& Lopez, 2007) underline forcefully that

[...] the demonization of neo-positive approaches has in many contexts made community work inoperative, producing perverse effect where by after lucid exercises in deconstruction and problematization communities are condemned by absolute relativism, impotence or refuge in a sterile intellectualism due to lack of operative instruments of action. (p. 313)
The need for CP innovative instruments for action that are not tied only to individualistic approach is stressed by in the conclusions of Reich, Riemer, Prilleltensky and Montero (2007), in which they note that their book about the development of community psychology worldwide, describes few innovative methodologies and they underline the need to develop more methodologies aimed beyond the individual and small group level: "One notable example was the Italian chapter, which has developed methods for community profiling, multidimensional organizational change as well as affective and empowering training" (pp. 430-431). Francescato, Tomai and Ghirelli (2002) tried to integrate the various theoretical and methodological viewpoints proposing that to promote $\mathrm{CP}$ values of social justice, diversity, and increasing the wellbeing of the most marginalized groups, CP interventions should:

a) Encourage pluralistic interpretations of social problems that integrate objective and subjective knowledge to broaden the viewpoints from which a given situation can be considered; b) Give voice to minority narratives and promote the production of new metaphors or new narratives that help 'imagine' new scripts and roles for individuals and social groups; c) Create ties among people who share a common problems; d) Identify the points of strengths to obtain change; e) Spread psychological knowledge and competencies; f) Increase participants' capacity to read power dynamics of contexts, seen from different perspectives, and to perceive obstacles and opportunities in each; g) Enable less empowered participants, especially women and minority members, to organize to reach desired changes.

Here, we describe in some detail three, intervention modalities theoretically grounded on the principles we just outlined.

\section{Innovative and theory driven CP intervention methodologies}

\section{Community profiling and network building}

The community profiling and network building intervention modality presented here was initially developed in Italy by two CP practitioners, Raffaello 
Martini and Roberto Sequi (1988), who proposed an analysis of community needs and strengths using seven profiles (territorial, demographic, economic, service, institutional, anthropological, and psychological). Austrian community and environmental experts (Ehmayer, Reinfeldt \& Gtotter, 2000), added innovative instruments such as walking photo tours by both members of the community and outsiders to examine the territorial profile and Francescato, Tomai and Ghirelli (2002) proposed an eighth profile assessing perceptions of the future of the community. So now this methodology views a local community from eight different perspectives, which encourages pluralistic interpretations of local problems that integrate objective and subjective knowledge. This technique integrates tools from different disciplines: demography, urban planning, environmental sciences, political science, economics, and anthropology. It activates forms of participation that acknowledge the importance of 'local knowledge.'

\section{The Community Profiling process}

Phase 1: Formation of core research group, data gathering and interviews with experts

Community Profiling begins with the formation of a core group of citizens made up of at least one local expert for each profile, the community psychologists involved, and representatives of the service agency or the political body sponsoring the research. This core group, through a brainstorming technique, performs a preliminary analysis, listing what they think are the strong and weak points of each profile. Key experts of each profile are then interviewed and their evaluations are then compared with the perceptions of the weak and strong points of the community identified by different groups of citizens.

Phase 2: Focus groups with dominant and marginalized groups of the community explore perceptions emotions, desires and fears for the future of the community

Groups are chosen to represent both dominant and marginalized members of a specific community.
To examine the anthropological, psychological and future profiles, a variety of more subjective small group techniques, from community narratives to group drawings, photo collages and movie scripts are utilized. Francescato, et al. (2002) have developed a special kind of focus group with four different phases:

Preliminary analysis: Participants use brainstorming techniques to come up with positive and negative aspects of their community. Brainstorming gives each participant a chance to express his or her opinion without being criticized. Each comment is then classified as primarily belonging to one of the eight profiles. This allows to determine which community profiles are perceived as more problematic and which are perceived more positively. It also gives a first measure on how empowered or disempowered participants perceive their communites: if more positive points are mentioned, this is seen as an indicator of a perceived empowered community; if more negative comments appear, it is an indicator of a perceived disempowered community.

2) Movie Script of their community: Participants are invited to develop a plot for a movie script about their community. They are invited to pick a genre of movie (e.g. historical, science fiction, comedy or detective) and come up with a title, a plot, and main characters. They can decide to present their movie script by narrating it, or they can also dramatize particular relevant scenes. The groups have about half an hour to create the movie script: each member is invited to propose a title, a plot line, a genre, and then they have to choose a final group movie script, which integrates various ideas and plot lines. A summary of the chosen movie script is then written on a large sheet of paper and hung up for all to see. After this creative phase and the presentation of its results through narration and dramatization, groups members are invited to discuss their movie script contents, the emotions they experienced and portrayed in the narratives, the problems and strengths that emerge from their narrative about their community.

3) Group discussion: Members discuss a) how they imagine their community in ten years, b) what 
are their major fears and c) what they desire most for the future of their community.

4) Final discussion Members outline possible solutions to identified problems and on how to obtain desired changes in their community.

Phase 3: Presentation of results and setting priorities for desired changes

In this final phase, a general meeting is held where all participants can view posted on the walls strong and weak points of each profile. Participants are invited to explore the interactions among main strengths and weaknesses that emerge from all eight profiles. Then they formulate the main priorities for change, identifying on which strong aspects of the community they can count on, to obtain desired changes in the most problematic aspects identified. Specific activities that need to be performed to achieve desired goals are also outlined and when possible, indications of persons, groups, networks or organizations that might be responsible for these initiatives are agreed upon.

The entire process of community profiling encourages networking among different associations, institutions, and small groups that create ties among people who share a problem and who can together; in the final meetings they identify the points of strengths to obtain a change. Performing a community profiling can take from two to six months, depending on how many interviews are conducted with key community experts and how many focus groups of dominant and marginalized members of the community are included in the process (Arcidiacono, Tuozzi \& Procentese, in press; Francescato, Tomai, \& Mebane, 2006; Francescato \& Zani, 2013). Several community profiles methodologies have been developed also by Hawtin, Hughes and Percy-Smith (2007), Kirsten and Holt (2008), Taylor and Burns (2000).

\section{B) Participatory Multidimensional Organizational Analysis (PMOA)}

Participatory Multidimensional Organizational Analysis (PMOA) is a methodology developed in the early eighties (Francescato \& Ghirelli, 1988) to facilitate a multi-faceted participatory organizational assessment of strengths, problem areas and workable solutions in an organization, to make it more empowered and empowering. Since then, Francescato and other colleagues, primarily community psychologists and work psychologists, have refined PMOA and tested it in many organizational settings (Francescato \& Aber, in press; Francescato, Tomai \& Mebane, 2004; 2006; Francescato, Tomai \& Solimeno, 2008; Francescato \& Zani, 2010; 2013).

\section{A brief description of PMOA in action}

PMOA involves individuals on all hierarchical levels in a specific organization. In organizations with less than thirty members, all participate in the evaluation process. In larger organizations a core group is formed, made up of representatives of all stakeholders. For instance, in a school, representatives of students, parents, teachers, janitors and office staff might analyze their organization across four dimensions. These four dimensions are assessed on a continuum that varies from dealing with 'hard' objective variables (market share, increase or decrease in number of students, number of students who drop out, opportunities and constraints offered by international, national, and local laws, by schools' internal regulations) to 'soft' subjective perceptions (unconscious representations of work settings, attitudes toward power, inter-group conflicts, level of satisfaction, etc.). The first dimension called the strategic and structural dimension, deals with the economic, legal, and political features of an organization. To facilitate collaborative organizational strategic planning of goals and desired outcomes, one has to monitor the environment in which an organization is embedded using also perspectives and tools developed by economists, sociologists and political scientists. The examination of the first dimension starts with an experienced member, who narrates the strategic history of the organization (i.e., when it was created, what goals and visions it had, how strategic goals have changed over time). Then members evaluate how their organization has 
fared, choosing various criteria with which to assess their organization's performance in the recent past. Taking into consideration legal, economic and other structural limits, and opportunities, the core group defines strategic objectives for the immediate future and for the next five years. Then the functional dimension is examined by reviewing what tasks have to be completed to meet goals. We use different methodologies taken from sociology and organizational disciplines to examine activity flows and detect where problems and assets may lie. To improve organizational functioning, to choose the action initiatives, which are helpful to reach desired outcomes, we also integrate concepts and tools from systems engineers and management experts.

Then the group examines the third psychodynamic dimension using a variety of tools drawn from cultural psychology, cultural anthropology and socio-analysis. This dimension explores group and individual emotional variables that are often not consciously discussed. This is done by analyzing group drawings, recurrent jokes, pictures hung on walls, etc. We also use 'the movie script technique', already described above, asking participants to make a movie script about their organization. Finally, the psycho-environmental dimension is explored which basically measures the fit between individuals' expectations and organizational aims. Generally, we use tools drawn from organizational psychology to measure constructs such as perceived leadership styles, individuals' competencies and potential, organizational climate and organizational health. To increase the congruence between individuals' and organizations' expectations, we have used both group and individual in-depth interviews focused on exploring the degree of fit between individual preferences, competences and desires and the organizational functions to be performed to reach strategic goals, formulated during the analysis of the structural and functional dimensions.

PMOA has been used by properly supervised master CP students, trained in this methodology to empower more than 140 organizations, ranging from public administration departments, volunteers and non profit organizations, hospitals, small business firms and schools (Francescato et al., 2008).
These new organizational empowering tools have spurred considerable interest in the global CP community. In fact, Italian community psychologists have been invited to hold workshops in several European countries, in South Africa, and in Latin America. These efforts have had some practical effects on academic CP training. Arcidiacono in her research (2013) found that in 2013 compared to the nineties more courses on organizational empowerment were offered in European CP programs and more chapters on the topic appear in several recent CP textbooks, especially in Germany and Italy. However, as in the USA, 'organizations' remain a minority or neglected topic in most CP programs. Recently there has been an increase in interest by USA based on organizational issues, with the publication of three special issues in the Journal of Community Psychology (Boyd, 2014; Boyd \& Angelique, 2002).

\section{C) Socio-political Empowerment Training}

To become empowered, a person needs first of all to be able to hope and to imagine a better future (hopefulness component). One also has to have objectives and take a variety of actions to reach them (efficacy component). Political empowerment begins when one is able to recognize the social opportunities and the obstacles present in the settings where one lives; and above all, understand the unequal power dynamics among individuals, groups, organizations, local communities and macro-social contexts. This intervention strategy integrates concepts and tools from the affective education movement, feminist consciousness raising groups, and Liberation Psychology. It is offered to both undergraduate and graduate students. In small group workshops, participants meet about ten times for three hours. Students first participate in consciousness raising activities by exploring how their needs and wishes are influenced by mass media. In this setting, students talk about their favorite songs, movies, Internet sites, social relationships and what values they convey. They also discuss their political socialization in the family, peer groups and school. Finally, they discuss their personal political social- 
ization that occurred through their use of particular social networks. These workshops aim also to help students become aware of how different branches of psychology are mainly the product of specific historical backgrounds and of the values and interests of their practitioners. Students are invited to imagine themselves working as community psychologists in settings of their choice. In pairs, students have to reflect on whether they possess the skills needed to do their desired jobs. Then students are asked to use the schema developed in the labs and in their community courses to detect the strong and weak points of the small groups of which they are members (family, class, work and/or volunteer) and to see how these groups impact on their personal, relational and collective well-being. Then, they do the same using the PMOA schema for an organization of their choice. Finally, using the profiling methodology discussed previously, they explore what they know and do not know about the community where they live or where they might want to work. They also discuss how the organization or community where they may work might be affected by broad cultural, economic and/or political changes. In the final two meetings, they assess the congruence between their desires and competences and what the outside world seems to offer and require and they identify priorities for personal change that they can manage on their own. For desired collective changes, they identify other people, groups and/ or institutions with which they have to network to achieve these wider goals (Bruscaglioni, 2007; Francescato \& Zani, 2010; 2013).

These three intervention modalities were taught face-to-face to students who could attend regular classrooms. However we have in Italy a large number of students who for lack funds or work engagements cannot come to class regularly. When forms of distance learning became more available with the Internet, we decided to experiment with online learning in 1999. Since then several community psychologists have become interested in using online platforms to disseminate $\mathrm{CP}$ values, theoretical principles and intervention modalities developed in various areas of the world. In the most recent international CP conferences (Puebla, Barcelona and Fortaleza) and in the
SCRA biennial meetings lively discussions have been held followed by the formation of an international group committed to develop forms of online learning in community psychology (SCRA's Base camp). To give a empirical contribution to this debate we now describe several studies we conducted to ascertain the comparative efficacy of face-to-face and online learning settings in teaching community profiling, $\mathrm{PMOA}$ and empowerment training modalities.

\section{Evaluating whether these three $\mathrm{CP}$ intervention methodologies could be taught through Computer Supported Collaborative Learning (CSCL) and Facebook}

\section{Key issues}

Computer Supported Collaborative Learning (CSCL) enables both independent as well as group learning. CSCL is based on cooperative and constructivist learning theories that focus on social interdependence and learning by students teaching one another. Supporters of CSCL (Biuk-Aghai $\&$ Simoff, 2004; Rudesstam, 2004) maintain that the social interaction available online can produce interpersonal effects even superior to those found in face-to-face groups and that it has the potential to provide new educational opportunities to teach even professional skills, normally taught only in face-to-face (F2F) graduate programs. Opponents instead think that the quality of education in online courses can be compromised because teaching and learning are dynamic processes that benefit from non-verbal cues present only in face-to-face settings (Walther, Loh, \& Grankia, 2005). Empirical data show contrasting results (Bernard, Abrami, Lou, Borokhovski, Wade, Wozney,... Huang, 2004; Jahng, Krug, \& Zang, 2007). Moreover, most studies vary in the type of collaborative learning that was promoted. This is a major limit, since there are different degrees of collaborative learning. On the low end of the continuum, a group might be brought together involuntarily, might have members who do not value collaboration, and might be given tasks 
and assessment that discourage collective behavior. At the high end of the continuum, a group might be created voluntarily, might be trained in specific collaborative techniques might be asked to complete tasks that require cooperation and might have their individual assessment tied to those of other group members (Sipusic, Pannoni, Smith, Dutra, Gibbons \& Sutherland, , 1999).

\section{Main aims of our studies comparing face-to-face and online seminars}

The first aim was to compare the efficacy of face to face and CSCL settings for teaching the three $\mathrm{CP}$ methodologies described in the first part of this paper: community profiling, PMOA, and sociopolitical empowerment training. The second aim was to compare the efficacy of the two settings in increasing various forms of students' self-efficacy, social capital and sociopolitical empowerment.

\section{Methodological features: How we organized teaching modules}

We conducted preliminary studies in the academic years 1999-2002 to ascertain which characteristics of learning settings increase efficacy of CSCL. We found that a high level of task and assessment sponsored cooperation, asynchronous communication, and presence of facilitating tutor following an empowering pedagogical model could improve learning experiences. We experimented with different kind of platforms, starting with Yahoo groups, Moodle and more recently Facebook groups. Although Moodle offered the best level of customization and configuration, Yahoo groups and Facebook groups were used because they were cost-free and easily available. Each of these platforms, though different, offered tools that permitted students to interact with other students and teachers and to share materials. For our online courses, we mostly used Forums to allow participants to have asynchronous discussions. In the area of 'Documents' both students and teachers were able to upload materials (such as word-processed documents) and eventually modify them together. Moreover,
'Documents' functions also as an archive: here we saved all theoretical materials, articles, and bibliographies. In the area called 'Polls' one can vote on different issues and the platform does all the counting and reports results. We planned micro modules with precise learning objectives and group tasks that could be done in the F2F threehour meetings and online the same week, so that sequences of group's tasks and exercises were held constant, as well as the pedagogical methodology based on collaborative learning. The students in both groups received the same theoretical materials, made the same practice exercises, and received feedback from the same teacher-tutor. We first performed a pilot study published in 2002 (Francescato, Porcelli, Mebane, Cuddetta, Klobas \& Renzi, 2006). In this research, fifty psychology majors, homogenous for gender, age and grade average, were assigned randomly to two seminars taught over a two-month period by the same teacher online and F2F, to learn the same professional skill: community profiling. All students, divided in ten small groups did a community profiling in a local community of their choice. The teacher, expert in both F2F and online teaching, designed small group collaborative learning activities into a seminar series consisting of weekly modules that could be completed both in F2F and online settings. The same teacher acted as content expert and process facilitator for both groups. The modules of the course were planned with precise learning objectives for each community profile with tasks that could be completed either in a weekly three-hour face-to-face meeting or online during the same week. Results showed that online and F2F participants achieved a similar growth in acquired knowledge and in the level of professional competence (measured through the evaluation of the 10 final group community profiles). Moreover, the two best community profiles were done by online students, who were also more efficient (four of the five online groups submitted their final analysis before all face-to-face groups).

In a second study (Francescato, Porcelli, Mebane, Attanasio \& Pulino, 2007) 166 psychology master level students were randomly assigned to four online and four F2F seminars held by the 
same teacher, focused on competencies of performing participatory multidimensional organizational analysis (PMOA). Students were divided in small groups (three to five students), which had to produce a final paper showing they had used the appropriate techniques learned in the seminars in a community organization of their choice (volunteer groups, community organizations, etc.). Two judges evaluated the 33 final papers. Both face-to-face and online students gained good competency with PMOA. Both types of courses improved students' empowerment, problem solving efficacy, and social efficacy. There was a significant increase in two of the three-empowerment subscales, dealing with perceived capacity to pursue aims and sociopolitical interest, in both online and face-to-face groups.

Our third study with 170 students (Solimeno, Mebane, Tomai \& Francescato, 2008) showed that students in both settings learnt equally well community profiling skills. In all our three studies social capital increases in both face-to-face and online settings. We did a follow up study, inquiring whether students had made new friends among their fellow seminar members, if they met face-toface and how often, if they heard or kept in touch by phone or email, and if they still studied or worked together. Nine months later online students kept in contact more often than F2F students (Mebane, Francescato, Porcelli, Iannone, \& Attanasio, 2008).

\section{Experimenting with blended (partially online and partially face to face) seminars using Facebook}

In our most recent study (Francescato \& Tomasiello, 2014) we explored if we could teach personal empowerment training techniques online using also Facebook groups' technology. Since $90 \%$ of the students used Facebook, using Facebook groups, saved us the time we had to spend with students familiarizing with the more complex platforms like Moodle. We used a blended methodology, classroom empowering interviews and focus groups, and sharing reflective comments on Facebook. In the classroom, in groups of three, students played three roles, taking turns in interviewing, being interviewed and observing the interactions. Interviews dealt with how family and media experiences had shaped their values, their aspirations and desires for the future. Then each triad posted each week their comments about the content and the process of their interaction. They also took turns facilitating focus groups about media and family influences in the classroom and posted each week their comments on group dynamics and facilitators' skills. All comments were available to all students, and the tutor also posted comments on how the individual triads, or the focus groups had worked. Results showed students learned the empowerment training methodology, increased their personal empowerment, sense of community and social capital.

\section{Main results and limits of these studies}

Taken together our evaluation studies show that CSCL, one of the most advanced form of online education, when done in small groups, characterized by high level of task and assessment sponsored cooperation, asynchronous communication, presence of facilitating tutor, can be used an innovative educational modality, to promote the diffusion of $\mathrm{CP}$ values, theoretical principles, and both traditional and innovative intervention methodologies. Our students learned community profiling, PMOA and empowering training techniques in CSCL settings as well as in traditional face-to-face classrooms, and increased their self-efficacy, social capital and personal empowerment.

One limit of our studies is that they were all conducted in Italy and need to be confirmed in other nations, but they indicate that community psychology values, principles and forms of practice elaborated in different parts of the world could easily become more available to community psychologists and social activists research in other countries.

\section{Conclusions}

Several community psychologists (Berghold \& Seckinger, 2007; Martin \& Lopez, 2007; Reich et al., 2007) argue that to promote the growth of community psychology we need to develop more 
structured intervention modalities based on a pluralistic approach. This paper seeks to contribute to the debate presenting three modalities of intervention that increase community, organizational and personal empowerment, developed by Italian community psychologists, and documenting how these professional skills can be learnt both face-to-face and online. There are several limits of which we are aware. First we focus on the concept of empowerment, which has been criticized by both critical and liberation community psychologists. Second, we have tried to integrate some elements of critical and liberation psychology in the development of these methodologies but more work needs to be done. We conceive of these modalities as 'works in progress' that can be enriched by contributions from community psychologists from other areas of the world. As Arcidiacono documents (2013) European community psychologists aim to integrate different ideas and methods. Online platforms can favor this international exchange that we hope will strengthen community psychology everywhere.

\section{References}

Amerio, P. (2000). Psicologia di comunità. Bologna: Il Mulino.

Arcidiacono, C. (2013). Reflections and action in CP ECPA Bulletin Issue, 1, 1-46. Retrieved from: http:// www.ecpa-online.eu.

Arcidiacono C, Tuozzi T., \& Procentese F. (2016). Community Profiling in Participatory Action Research. In Jason, L. A., \& Glenwick, D. S. (Eds.). Handbook of methodological approaches to community based research: Qualitative, quantitative, and mixed methods. New York, NY: Oxford University Press.

Bergold, J., \& Seckinger, M. (2007). Community Psychology between Attitude and Clinical Practice: The German Way. In International Community Psychology (pp. 238-262). Springer US.

Bernard, R. M., Abrami, P. C., Lou, Y., Borokhovski, E., Wade, A., Wozney, L., ... Huang, B. (2004). How Does Distance Education Compare With Classroom Instruction? A Meta-Analysis of the Empirical Literature. Review of Educational Research, 74, 379-439.
Biuk-Aghai, R. P., \& Simoff, S. J. (2004, November). Patterns of Virtual Collaboration in Online Collaboration Systems. Paper presented at the IASTED International Conference on Knowledge Sharing and Collaborative Engineering, St. Thomas, USVI, November 22-24, 57-62.

Boyd, N. M. (2014). A 10-year retrospective of organization studies in community psychology: content, theory, and impact. Journal of Community Psycho$\log y, 42,237-254$.

Boyd, N., \& Angelique, H. (2002). Rekindling the discourse: Organization studies in community psychology. Journal of Community Psychology, 30, 325-348.

Bruscaglioni, M. (2007). Persona empowerment. Poter aprire nuova possibilità nel lavoro e nella vita. Milano: Franco Angeli.

Ehmayer, C., Reinfeldt, S., \& Gtotter, S. (2000, may 12). Agenda 21 as a concept for sustainable development. Paper presented at III Panel of Experts, May $12^{\text {th, }}$ Vienna.

Francescato, D., \& Aber, M. (In press). Learning from Organizational theory to Build Organizational Empowerment Journal of Community Psychology. .

Francescato, D., \& Ghirelli, G. (1988). Fondamenti di psicologia di comunità. Roma: Carocci.

Francescato D., Porcelli R., Mebane M.E., Attanasio, C., \& Pulino, M. (2007). Developing Professional Skills and Social Capital Through Computer Supported Collaborative Learning in University Contexts. International Journal of Human Computer Studies, 65, 140-152.

Francescato, D., Porcelli, R, Mebane, M., Cuddetta M., Klobas, J., \& Renzi, P. (2006). Evaluation of the Efficacy of Collaborative Learning in Face to Face and Online Contexts, Computers in Human Behavior, 22,163-176.

Francescato, D., \& Tomai, M. (2001). Community Psychology: Should there be a European perspective? Journal of Community and Applied Social Psychology, 11, 371-380.

Francescato, D., Tomai, M., \& Ghirelli, G. (2002). Fondamenti di psicologia di comunità. Roma: Carocci.

Francescato, D., Tomai, M., \& Mebane, M. (2004). Psicologia di comunità per la scuola, l'orientamento 
e la formazione. Esperienze faccia a faccia e online. Bologna: Il Mulino.

Francescato D., Tomai M., \& Mebane, M. (2006). Psicología comunitaria en la enseñanza y la orientacion. Experiencias de formacion: presencial y online. Madrid: Narcea.

Francescato, D., Tomai, M., \& Solimeno, A. (2008). Lavorare e decidere meglio in organizzazioni empowered e empowering. Milano: Angeli

Francescato, D., \& Tomasiello (2014, june). Apprendere la Formazione Empowering collaborando su Facebook, un esperienza pilota. Paper presented at the National Conference of SIPCO, Cesena, June 19th-21st.

Francescato, D., \& Zani, B. (2010). Community psychology in Europe: more needed, less wanted. Journal of community and applied social psychology, 20, 445-455.

Francescato, D., \&Zani, B. (2013). Community Psychology Practice Competencies in Undergraduate and Graduate Programs in Italy. Global Journal of Community Psychology Practice, 4(4), 1-12. Retrieved from: http://www.gjcpp.org/pdfs/2013-001CCSI-20131018.pdf

Hawtin, M., Hughes, G., \& Percy-Smith, J. (2007). Community profiling. A practical guide. Maidenhead, England: Open University Press.

Jahng N., Krug D, \& Zhang Z. (2007). Student Achievement in Online Distance Education Compared to Face-to-Face Education. The European Journal of Open and Distance Learning, 2007-I. Retrieved from: http://www.eurodl.org/materials/contrib/2007/Jahng_Krug_Zhang.htm

Kirsten, J., \& Holt, M. (2008). Community profiling as part of a health needs assessment. Nursing Standard. 22, 51-56.

Martin, A. \& Lopez, J. (2007). Community psychology in Spain: Realities, expectations and desires. In Reich, S., Riemer, M., Prilleltensky, I., \& Montero, M. (Eds.). History and theories in community psycho- logy. An international perspective (pp. 299-316). New York, N.Y: Springer.

Martini, R., \& Sequi, R. (1988). Il lavoro nella comunità. Roma: Carocci.

Mebane, M., Francescato, D., Porcelli, R., Iannone, A., \& Attanasio, C. (2008). Evaluation of the efficacy of affective education online training in promoting academic and professional learning and social capital. International Journal of Human-Computer Interaction, 24, 1-19.

Orford, J. (2008). Community Psychology: Challenges, controversies, and emerging consensus. Chichester: John Wiley.

Ornelas, J. (2008). Psicologia comunitaria. Lisboa: Fim de seculo.

Reich, S. M., Riemer, M., Prilleltensky, I., \& Montero, M. (Eds.). (2007). International Community Psychology: History and Theories. New York: Springer.

Rudestam, K. E. (2004). Distributed Education and the Role of Online Learning in Training Professional Psychologists. Professional Psychology: Research and Practice, 34, 427-432.

Sipusic, M. J, Pannoni, R. L., Smith, R. B., Dutra, J., Gibbons, J. F., \& Sutherland, W. (1999). Virtual Collaborative Learning: A Comparison Between Face-to-Face Tutored Video Instruction (TVI) and Distributed Tutored Video Instruction (DTVI). Palo Alto, California: Final Report Sun Microsystems.

Solimeno, A., Mebane, M., Tomai, M., Francescato, D. (2008). The influence of students and teachers characteristics on the efficacy of face to face and computer supported collaborative learning. Computers and Education, 109-128.

Taylor, M., \& Burns, D. (2000). Auditing community participation: An assessment handbook. Bristol, England: Policy Press.

Walther, J. B., Loh, T., \& Granka, L. (2005). Let Me Count the Ways. The Interchange of Verbal and Nonverbal Cues in Computer-Mediated and Faceto-Face Affinity. Journal of Language and Social Psychology, 24, 36-65. 
